\title{
Article
}

\section{Reuse of Barley Straw for Handmade Paper Production}

\author{
A.D. Román-Gutiérrez ${ }^{1}$, Juan Hernández Avila.. ${ }^{*}$, Antonia Karina Vargas M.1, Eduardo Cerecedo S.2, Eleazar \\ Salinas $\mathbf{R}^{2}$. \\ 1 Academic Area of Chemistry, Institute of Basic Sciences and Engeneering, Autonomous University of Hi- \\ dalgo State, Highway Pachuca - Tulancingo km. 4.5, C.P. 42184, Mineral de la Reforma, Hidalgo, Mexico; \\ aroman@uaeh.edu.mx (A.D. R-G), qkarinavm@gmail.com (A. K. V-M). \\ 2 Academic Area of Earth Sciences and Materials, Institute of Basic Sciences and Engeneering, Autonomous \\ University of Hidalgo State, Highway Pachuca - Tulancingo km. 4.5, C.P. 42184, Mineral de la Reforma, Hi- \\ dalgo, Mexico; C.P. 42184, México; salinasr@uaeh.edu.mx (E.S.-R.), mardenjazz@yahoo.com.mx (E.C.-S.). \\ * Correspondence:) herjuan@uaeh.edu.mx (J.H.-A.);Tel.: +52-771-125-8798
}

\begin{abstract}
Usually in the manufacture of beer by fermentation of barley, in both industrialized and developing countries significant amounts of organic solid waste are produced from barley straw. These possibly have an impact on the carbon footprint with an effect on global warming. According to this, it is important to reduce environmental impact of these solid residues, and an adequate way is the recycling using them as raw material for the elaboration of handmade paper. Therefore, it is required to manage this type of waste by analyzing the environmental impact, and thus be able to identify sustainable practices for the treatment of this food waste, evaluating its life cycle, which is a useful methodology to estimate said environmental impacts. It is because of this work shows the main results obtained using the life cycle analysis (LCA) methodology, to evaluate the possible environmental impacts during the waste treatment of a brewery located in the state of Hidalgo, Mexico. The residues evaluated were barley straw, malt residues and spent grain, and at the end, barley straw was selected to determine in detail its environmental impact and its reuse, the sheets analyzed presented a grammage that varies from $66 \mathrm{~g} / \mathrm{m} 2$ and $143 \mathrm{~g} / \mathrm{m} 2$, resistance to burst was 117 to $145 \mathrm{kpa}$, with a crystallinity of $34.4 \%$ to $37.1 \%$.
\end{abstract}

Keywords: Barley straw; Straw, Handmade paper; Properties

\section{Introduction}

Actually, technological advance does not go hand in hand with the consumption of craft paper. Regarding the craft paper, its consumption is increasing [1]. Today, much of the information can be digitized, but the use of paper is still essential. That is why the cutting of forest increases; and some figures show that from 2000 to 2012, the planet lost 2.3 million $\mathrm{km} 2$ of forest [1]. For this reason, it is extremely important to seek other sources to obtain alternative raw material for the paper industry.

Some innovative alternatives for this type of industry are the so - called lignocellulosic materials, which represent an important source of polymeric materials of industrial interest, due to their renewable origin. Some materials of plant origin such as corn stalks, pineapple crown, rice husk, flax, rice straw, barley straw, oat straw, and wheat straw, have been used as an alternative raw material to wood, for its application in the manufacture of paper, achieving favorable results and this gives added value to this type of materials [2].

On the other hand, the quality of the paper depends on whether it has the necessary properties for its intended use. Which will depend fundamentally on the raw materials used; the type of fibers, the crystallinity and the processes to which they are subjected in their suitability for the production of paper $[3,4]$.

In this context, the main objective of this work is to support the use of sustainable solutions for the management and reuse of waste from the food industry, making sheets of artisan paper innovating the process with the use of different proportions of cellulose 
obtained from spent barley straw, sheets of recycled paper, and the evaluation of their quality through the implementation of different methods. As well as determining the industrial viability for the elaboration of artisan paper with the aforementioned materials, since Mexico is currently one of the main beer producers in the world, which means that it generates significant amounts of waste materials such as straw. barley that will be used for this purpose and makes it so, a suitable raw material that in the end will have added value [5].

\section{Materials and Methods}

To carry out this research work, samples of oat straw, barley, and triticale were used, which were produced in the municipality of Apan, belonging to the State of Hidalgo, Mexico.

The straw sampling was of the simple random type, in which the units were chosen individually and directly through a random process [6].

The granulometric analysis was carried out by dry method. Prior to the sieving, a pretreatment was carried out that consisted of a reduction in the size of the straw and glume (it was crushed for 6 minutes in a blender), later the analysis was carried out with standard sieves (Tyler MR series), No. 14 , 18, 30, 40, 50. Subsequently, a $20 \mathrm{~g}$ sample was sieved, and the obtained fractions were weighed.

During the chemical analysis of the straw, humidity was calculated according to the method 925.10 of the Association of Official Analytical Chemists (AOAC), [7]. In which 5 $\mathrm{g}$ of grinded sample were weighted, then sample was heated in a reticulating air oven at $378 \mathrm{~K}+/-3 \mathrm{~K}$ during 4 hours. After that time, the trays got cold to room temperature in a dissector for to be weighted again.

Ash determination was carried out using the AOAC method 923.03 [7]. This was done by incinerating the straw sample until obtaining a fraction of the sample ashes. It was determined from $2 \mathrm{~g}$ of sample using a muffle Fisher Scientific located at the Autonomous University of Hidalgo State, working at a temperature of $823 \mathrm{~F}$. The fat analysis was carried out on a LECO model TFE 200 fat extraction equipment, using supercritical CO2 with a pressure of $9000 \mathrm{~kg} / \mathrm{cm} 2$ PSI. For this essay, $0.20 \mathrm{~g}$ of dry straw was used.

The determination of proteins and nitrogen was done using the Dumas method [8], in an equipment LECO FP-528.

The holocellulose content was determined using the Wise method, [9,10]. $5 \mathrm{~g}$ of extractables-free straw were weighed, and the material was placed in an Erlenmeyer flask with a solution containing $1.5 \mathrm{~g}$ of $\mathrm{NaClO} 2$ in $160 \mathrm{ml}$ of water, to which 10 drops of acetic acid were previously added, and the samples they were kept in a water bath at a temperature of $348 \mathrm{~K}$ for one hour. After that time, $1.5 \mathrm{~g}$ of sodium chlorite $(\mathrm{NaClO} 2)$ and 10 drops of acetic acid were added, it was stirred and left to stand, the previous procedure was repeated until 4 hours were completed. Subsequently, it was allowed to warm and filtered, washed with hot water and then with acetone, the filtrate was dried at $318 \mathrm{~K}$ and the holocellulose content was determined. 


\subsection{Lignocellulosic Composition of Straw}

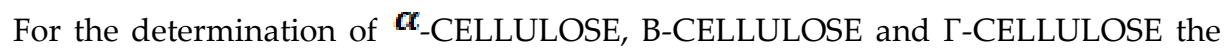
technique [TAPPI $203 \mathrm{om}-88$ ] was used; During the procedure, $1.5 \mathrm{~g}$ of extractable - free straw (subjected to holocellulose determination) were placed in a $250 \mathrm{ml}$ Erlenmeyer flask, $75 \mathrm{ml}$ of the $17.5 \%$ sodium hydroxide reagent were added, and it was stirred until the mixture was completely homogeneous. After a period of 30 minutes, $100 \mathrm{ml}$ of distilled water at $298 \mathrm{~K}+/-2 \mathrm{~K}$ was added to the suspension, and it was stirred, left in a water bath for another period of 30 minutes and finally filtered.

For the determination of alpha-cellulose, $10 \mathrm{ml}$ of the filtrate and $20 \mathrm{ml}$ of a $0.5 \mathrm{~N}$ potassium dichromate solution were taken and placed in a $250 \mathrm{ml}$ flask. $30 \mathrm{ml}$ of concentrated $\mathrm{H} 2 \mathrm{SO} 4$ were added, the solution remained hot for 15 minutes, then $50 \mathrm{ml}$ of water were added and it was cooled to room temperature, 3 drops of indicator "ferroin (C36H24FeN62)" were added and it was titrated with the solution of ferrous ammonium sulfate [(NH4) 2Fe (SO4) 2.6H2O] $0.1 \mathrm{~N}$ until a purple color is obtained.

The blank titration was performed by replacing the material filtrate with $5 \mathrm{ml}$ of $17.5 \%$ $\mathrm{NaOH}$ and $5 \mathrm{ml}$ of $\mathrm{H} 2 \mathrm{O}$.

The determination of beta and gamma-cellulose was carried out by taking $50 \mathrm{ml}$ of the filtrate and placing it in a $250 \mathrm{ml}$ flask, adding $50 \mathrm{ml}$ of $\mathrm{H} 2 \mathrm{SO} 43 \mathrm{~N}$ and mixing. The flask was heated for 5 minutes by immersing it in a hot water bath, at a temperature between $343 \mathrm{~K}$ and $363 \mathrm{~K}$, to coagulate the beta-cellulose. The precipitate was allowed to settle overnight.

Subsequently, a blank titration was made, replacing the solution with $6.25 \mathrm{ml}$ of $17.5 \%$ $\mathrm{NaOH}$ and $6.25 \mathrm{ml}$ of $\mathrm{H} 2 \mathrm{O}$, to which $20 \mathrm{ml}$ of $3 \mathrm{~N} \mathrm{H} 2 \mathrm{SO} 4,10 \mathrm{ml}$ of $0.5 \mathrm{~N}$ potassium dichromate and $50 \mathrm{ml}$ were added of $\mathrm{H} 2 \mathrm{O}$.

Lignin was determined by the Klason method according to the Standard [TAPPI T222om-88]. $5 \mathrm{~g}$ of straw were used, it was placed in a beaker, adding $15 \mathrm{ml}$ of $72 \% \mathrm{H} 2 \mathrm{SO} 4$ to it, and the beaker was covered with a watch glass and kept at $293 \mathrm{~K}$ for two hours. The mixture was diluted to make up the volume to $575 \mathrm{ml}$ with distilled water, this solution was boiled for four hours, keeping the volume constant by adding hot water, it was allowed to warm, it was filtered and the residue was left to dry to constant weight to determine the lignin content.

\subsection{Preparation and Evaluation of Handmade Paper Sheets Cooking Process, (Thermal-Alkaline)}

According to the methodology of Al Arni et al., [11]. The residues (100 g) were suspended in $200 \mathrm{ml}$ of $\mathrm{NaOH} 2.0 \mathrm{M}$ and placed in an autoclave at $394 \mathrm{~K}$ for 60 minutes, then they were filtered and washed with water until neutral at $\mathrm{pH} 7$. Once the cellulose was obtained, it was ground in an Osterizer blender on the fifth speed for 6 minutes, to obtain the cellulose pulp.

The craft paper sheets were made with cellulose pulp obtained from straw and recycled paper, with the proportions shown in table 1. 
Table 1. Proportions of barley straw (BS), and recycled paper (RP) for making craft paper.

\begin{tabular}{|ccc|}
\hline Sheet & $\%$ BS & $\%$ RP \\
\hline A & 0 & 100 \\
B & 20 & 80 \\
C & 40 & 60 \\
D & 50 & 50 \\
E & 60 & 40 \\
F & 80 & 20 \\
G & 100 & 0 \\
\hline
\end{tabular}

Once the cellulose pulp was obtained from both barley straw and recycled paper, a volume of $60 \mathrm{ml}$ of pulp was taken for each mixture and added to a wooden sieve, which was immersed in water. Subsequently, the pulp was stirred to homogenize it throughout the area, and the sieve was removed to drain the water.

After getting the sheet into the sieve, it was removed and pinch was added; the sieve was turned upside down and with the help of a wooden shovel the excess water was removed and the bolt removed from the strainer, and a second bolt cap was immediately fitted.

Once there were 10 sheets, a $10 \mathrm{Kg}$ press was used for pressing, which was carried out for 30 minutes. Once the sheets were pressed, they were flattened with the help of a wooden roller in order to erase the marks resulting from the sieve mesh, then they were allowed to air dry for 12 hours, and at the end of that time the pellet was removed.

The physical properties of the produced paper were obtained, using different standards; the determination of grammage or base weight of the paper was carried out based on the [NMX-N-001-SCFI-2005] [12] Standard, for thickness, the standard was [NMX-N-009-SCFI-2005] [13] and for resistance upon bursting, Standard [NMX-N-087-SCFI-2008] [14] was used.

For the characterization of the different craft papers produced, the following instrumental analysis techniques were used: X-ray diffraction, which was carried out in an Inel Diffractometer, model 2000 located at the Autonomous University of the State of Hidalgo (UAEH), Mexico . The MATCH database was used to index the spectra obtained in this analysis. It was necessary to prepare the sample to $33 \mu \mathrm{m}$ mesh. The morphology of the samples was obtained with the help of a scanning electron microscope (SEM), model JEOL JMS 6300 (located in UAEH) with a voltage of $30 \mathrm{keV}$ and equipped with an Energy Dispersive X-ray Detector Spectrometer (EDS), for which the samples were dried in an oven (Fisher Scientific) at a temperature of $318 \mathrm{~K}+-2 \mathrm{~K}$ for 3 days.

On the other hand, IR spectrophotometry was performed with a Perkin Elmer Flouries equipment (located at UAEH). The thermogravimetric analysis (TGA) was carried out under the following conditions: nitrogen flow of 4 cubic $\mathrm{cm}$ per minute, temperature of 323 to $653 \mathrm{~K}$ and in duplicate it was carried out with a Mettler Toledo equipment (located at UAEH). Differential Scanning Calorimetry (DSC) analysis was carried out with tem- 
perature ranges from 323 to $473 \mathrm{~K}$ with a heating rate of $283 \mathrm{~K} / \mathrm{min}$, and the analyzes will be carried out in duplicate with a Mettler Toledo equipment (located at UAEH).

\section{Results and Discussion}

The results of the granulometric analysis are shown in figure 1, where the average of the replications made can be observed, the 3 samples have a similar size distribution since all have a greater retention in a size of $600 \mu \mathrm{m}$ with $26 \%$, between $5-8 \%$ for a size of $1400 \mu \mathrm{m}, 15 \%$ for $1000 \mu \mathrm{m}, 25 \%$ for $600 \mu \mathrm{m}, 15-18 \%$ for $300 \mu \mathrm{m}$ and the fines with an approximate percentage of $30 \%$.

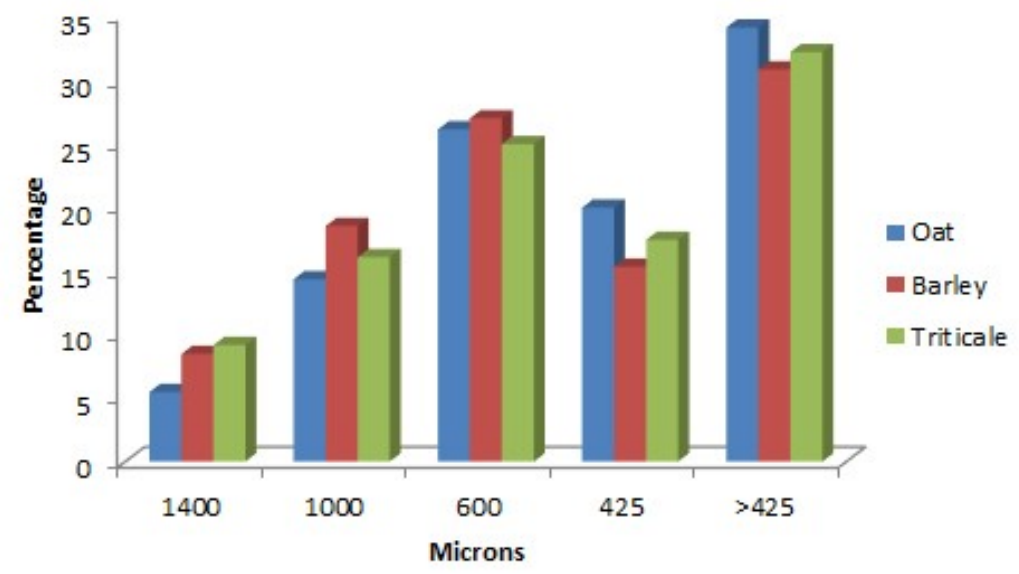

Figure 1. Granulometric distribution of the straws.

All figures and tables should be cited in the main text as Figure 1, Table 1, etc. For a similar study [15], an interval ranging from $200 \mu \mathrm{m}$ to $2 \mathrm{~mm}$ was used, and Barba [16], in their methodology with a range from $320 \mu \mathrm{m}$ to $2 \mathrm{~mm}$ [16]. On the other hand, Pepijn [17] recommends a size of $2 \mathrm{~mm}$ and $1 \mathrm{~mm}$. Reasons why it was established that the particle size would be $1.4 \mathrm{~mm}-425 \mathrm{\mu m}$ for oat straw, barley and triticale [16].

According to the results obtained, the straw that presented a size of $600 \mu \mathrm{m}$ was taken to perform the chemical analyzes, since this is within the parameters reported by different authors, and this sieve presented greater retention. In the case of the fines that presented a $30 \%$ retention, these are considered as lost since, due to what was reported by Téllez [18], they presented an overcooking.

The results of humidity, ash, fat, protein and holocellulose for the three samples are observed in table 2, which presented an average humidity of $9.7 \%$. Being oat straw, which showed the highest value with $11.9 \%$, followed by triticale straw with $9.1 \%$ and finally barley straw with $8.1 \%$. A similar percentage is reported by Torres [19], for oat straw with $8.1 \%$, a percentage that is less than the $11.9 \%$ obtained for that same cereal straw.

Regarding triticale straw, it showed a moisture content of $9.1 \%$, similar to that reported by Contreras [20], with $9.5 \%$ for barley ears, but higher than the $8 \%$ reported by Seoánez et al., [21]. Barley straw was the one that obtained the lowest percentage with $8.1 \%$, as reported by Yescas [22] for oat straw, similar to the $8 \%$ reported by Seoánez et al., [21]. Therefore, the low moisture content presented by the samples is favorable [23], since the ranges obtained 
in this investigation of the raw material are within the specifications for the manufacture of paper.

The results of the ash content are shown in table 2, in which it can be observed that these vary from $4-6 \%$, being the barley straw the one that showed a higher percentage with $5.7 \%$, followed by the triticale straw and oat straw with $4.5 \%$. Which agrees with that reported by Tomas [24] and Torres [25], who obtained values of $4.7 \%$ and $3.5 \%$ respectively, and similar to that obtained for oat straw and triticale, even lower than these values. Gonzáles [26] reports $10.9 \%$ for wheat straw, a percentage that is higher than that of the three samples analyzed, and the sample that is closest to this percentage is barley straw. Pepijn [17] and Barba [16], reported similar results of $6.6 \%$ and $6.8 \%$ respectively, which are close to that obtained for the straw analyzed in this work.

According to the data obtained, the ash content is less than $6 \%$ in all the samples, which is good because in this type of compounds the content must range between $1-10 \%$. However, the values in this type of samples may vary due to various factors such as: the type of irrigation either with drinking water or with contaminated water, the application of pesticides, the type of soil, the region, and the climate.

The fat content can be observed in table 2, where it is observed that the equipment did not detect it because it was very low, less than $1 \%$, which is acceptable since the percentage of fat in this type of samples is of $1 \%$ approximately as reported by Seoánez et al., [21]. The above, agrees with what was found by Torres [25], who obtained a fat content of $1.0 \%$ for oat straw, another author who agrees with the previous ones in Gonzales [26] who reports a content of $1.11 \%$.

Due to the type of sample that was analyzed, this result is within the norm, in addition to which it is important to highlight that this type of compound intervenes in the elaboration of the paper, since they generate imperfections in the form of stains that are perceptible in the final product.

Table 2. Chemical composition of the three varieties of straw, expressed as a percentage on a dry basis (Standard deviation).

\begin{tabular}{|cccccc|}
\hline Straw & Humidit & Ash & Protein & Grease & holocellulos \\
& $\mathrm{y}$ & & & & $\mathrm{e}$ \\
Oat & $11.9(0.4)$ & $4.7(0.1)$ & $8.6(0.4)$ & $\mathrm{ND}$ & $71.5(0.7)$ \\
Barley & $8.1(0.2)$ & $5.7(0.05)$ & $10.3(0.3)$ & $\mathrm{ND}$ & $70(0.3)$ \\
Triticale & $9.1(0.2)$ & $4.8(0.05)$ & $8.9(0.2)$ & $\mathrm{ND}$ & $73.4(0.5)$ \\
\hline
\end{tabular}

For protein content, table 2 shows the average of the replications made for oat straw, barley and triticale. It can be seen that the three types of straw present a similar protein percentage which ranged between $8-11 \%$. Barley straw being the sample that presented the highest percentage with $10.3 \%$, followed by triticale straw with $8.9 \%$, and finally oat straw with $8.9 \%$.

Barley straw had a content greater than $10 \%$, which is close to that reported by Gonzáles [26], who obtained $12.16 \%$ for wheat straw. 
On the other hand, Torres [25] reported a protein content of $4.9 \%$ for barley straw, a value that is below that obtained for that cereal straw in the present work, which is $8.6 \%$. Bartaburu [27], reports that the protein content in cereal straw is $4-5 \%$, and specifically for rice straw it is $3.2-4.6 \%$, a percentage that is below that obtained for oat straw, barley and triticale.

The low protein content in the samples is a good factor, since this type of compound is not of interest in the paper industry, since these are eliminated during the process of obtaining cellulose and paper.

On the other hand, the holocellulose content, which is the largest constituent of the straw of these cereals, since this represents the total of carbohydrates, cellulose and hemicelluloses, present in a lignocellulosic material [9, 28].

Table 2 shows the percentage of holocellulose for the analyzed samples, in which it is observed that triticale straw presents the highest percentage of holocellulose with $73.4 \%$, followed by oat straw with $71.5 \%$ and finally the barley straw with $70 \%$.

As can be seen, the results obtained in this analysis are very promising since all the samples present a percentage higher than $70 \%$, the sample that obtained the highest percentage of holocellulose was the triticale straw with $73 \%$ which is very close to what Jiménez [29] reports for wheat straw being $72.6 \%$. Also, it is similar to some woods that Jaucida [30] such as oak and chestnut with $74.9 \%$ and $71.3 \%$ respectively.

With regard to Oat straw, this has a percentage of $71.5 \%$, and barley straw is the one with the lowest content of holocellulose with $70 \%$ which is similar to the $68.8 \%$ present in cypress wood, according to Jaucida [30]. According to what was reported by Pepjin [17], for wheat straw with a percentage of $67 \%$ the results obtained are above this value, for this reason it is a good result.

This data is of great importance since the results are close to those found in some woods, these being the main raw material in the production of paper, which gives us an idea of the possible cellulose yield that will be obtained.

\subsection{Lignocellulosic Composition of Cereal Straw}

The results obtained from the analyzes carried out on the straw samples are shown in table 3, as observed in said table, oat straw has the highest alpha-cellulose content with $49.0 \%$, while barley straw presents an alpha cellulose content of $46.4 \%$ and finally the triticale straw presented the lowest content with $32.1 \%$. A similar percentage reported Pepijn [17], with an alpha-cellulose content of $55.6 \%$ for wheat straw, which is close to that obtained for oat straw, which has the highest percentage of alpha-cellulose with 50.3\%.

On the other hand, Barba [16] obtained an alpha-cellulose content of 31-37\% for oat straw, which is below the content obtained in the present work. The second sample with the highest percentage was barley straw with $46.4 \%$, which agrees with that reported by Jiménez [23], for wheat straw with $40 \%$, while triticale straw showed the lowest alpha-cellulose content with $32 \%$, a percentage that is similar to that mentioned by Cuervo [15] with 30\% and Gonzáles [26], for rice straw with 35\%, and for this reason this sample will have a lower 
yield compared to the others.

Likewise, some of the results obtained were above that reported by Hernández [10], for wheat straw with $32 \%$ and rye straw with $34 \%$, with the exception of triticale straw, which contains $30 \%$.

The results obtained are favorable for the elaboration of artisan paper since the cellulose content is greater than $45 \%$ [12] in both oat straw and barley straw.

For this reason, triticale straw, as it has a lower content of cellulose, which is the main compound in paper, is less viable for this application.

Regarding the content of gamma-cellulose, which refers to the content of hemicellulose present in MLC, as observed in.

Table 3, triticale straw, showed the highest gamma-cellulose content with $8.3 \%$. Followed by oat straw with $6.8 \%$ and finally barley straw presented the lowest hemicellulose content with $5.3 \%$. The percentage of cellulose range ranged between $6-9 \%$, being the triticale straw the one that presented a higher content of hemicellulose with $8.3 \%$ percentage that is close to that reported by Gonzáles [26], for rice straw with $12 \%$.

Likewise, flax contains $12 \%$, according to Marques [31], a value that is close to that obtained for the analyzed samples, but well below that reported by Hernández [10], for wheat straw and rye the content of hemicellulose is 29 and 28\%, respectively. For his part, Quintero [32] reports a hemicellulose content of $28 \%$ for barley straw, $25 \%$ for rice straw and $20-26 \%$ for wood, all the samples analyzed are below that reported by said author.

The hemicellulose content in the samples is favorable because its main function is its interaction with cellulose and lignin. How hemicellulose chains associate with cellulose microfibrils due to their polar character (hydrogen bonds), resulting in visco-elastic behavior, important to provide good properties such as degree of swelling, flexibility, rigidity, hardness, etc. . during the papermaking process.

Table 3. Lignocellulosic composition of the three straw varieties, in percentage dry base (Standard deviation).

\begin{tabular}{|cccc|}
\hline Straw & $\% \alpha$-cellulose & $\% \gamma_{\text {-cellulose }}$ & $\%$ Lignin \\
& & & \\
Oats & $49.0(0.3)$ & $6.8(0.1)$ & $15.1(0.4)$ \\
Barley & $46.4(1.9)$ & $5.3(0.1)$ & $12.8(0.4)$ \\
Triticale & $32.9(3.0)$ & $8.3(0.2)$ & $14.0(0.3)$ \\
\hline
\end{tabular}

As can be seen in table 3, the lignin content present in the oat straw, barley and triticale samples ranged between $11-15 \%$, and it is the oat straw that shows the highest lignin content with $11.5 \%$, while barley straw and triticale showed similar percentages of lignin with $13.9 \%$ and $14.4 \%$ respectively. Something similar mentions Marques [31], who reports a lignin content for cereal straw that ranges from $12-21 \%$, an interval in which the results obtained for barley straw and triticale enter with $13.9 \%$ and $14.4 \%$ respectively. The results 
are similar to that reported by Pepjin [17] for wheat straw with 16\%, which is lower than that reported by the same author for coniferous wood with $25-33 \%$, for this reason this result is very favorable. For his part, Jiménez [23] indicates a lignin content for bean straw of $9 \%$, a value that is below the value obtained for the three samples analyzed.

According to the results obtained, they are lower than the lignin content in wood, which is important because the lignin content affects the color of the cellulose pulp, therefore, the higher the lignin content, the greater the expense in the whitening process if applicable.

\subsection{Characterization of the Straws by SEM}

On the other hand, the results of the characterization of the straws by SEM are presented in Figure 2, where the internal microstructures of the different samples analyzed are shown, the micrographs $(\mathrm{A}-\mathrm{C})$ of oat straw show a transverse shot, in the which shows a set of individualized vascular bundles, between the parenchyma tissue, which are well structured, cylindrical, compact and continuous, in addition to not presenting fissures.

In the micrographs (D-F) that belongs to the triticale straw, a smooth, cylindrical, compact and continuous surface, well structured, is observed. While for barley straw the (G-I), shows a horizontal cut, where it can be seen that it presents fibers that tend to be irregular in the cuts, for this reason the fibers do not show a uniform cut if not the opposite. However, it can be seen that the straw has an agglomerate of cellulose fibers due to its circular or oval shape.
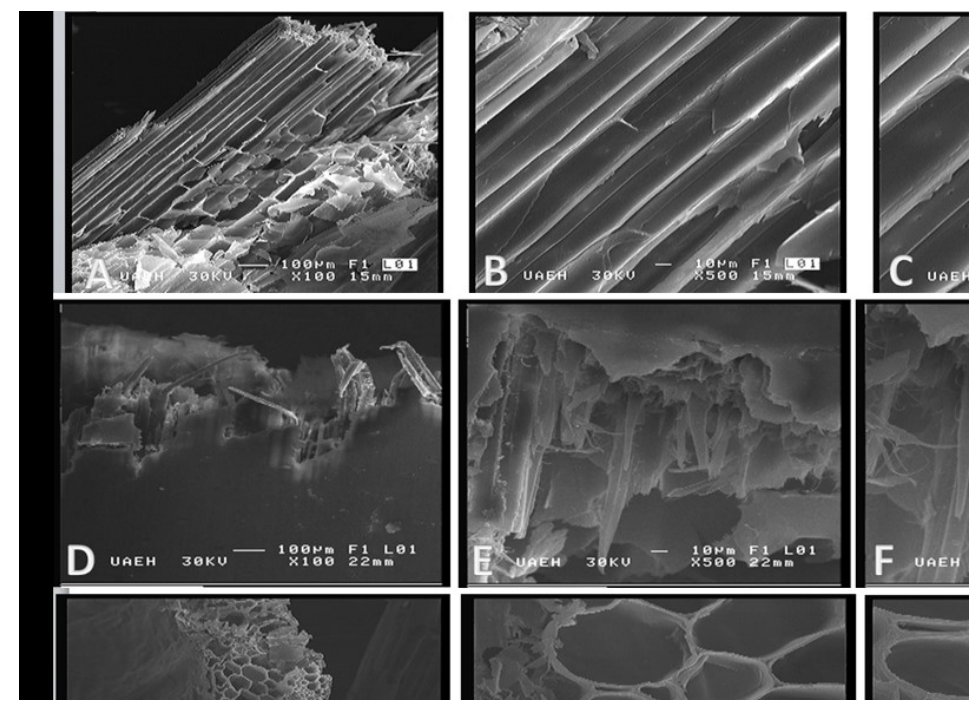

Figure 2. Micro-photographs of straw of Oats (A-C), Barley (D-F) and Triticale (G-I).

On the other hand, the structure of barley straw, being less complex than that of wood $[23,33]$, allows chemical reagents to better eliminate the compounds that are desired for the paper industry Furthermore, as it has a lower lignin content, this will reduce the bleaching process, which is why it was determined that barley straw would be used to make the paper. 


\subsection{Obtaining and Evaluating Sheets of Craft Paper}

7 leaves were made from each of the different proportions of barley straw (BS) and recycled paper (RP), with dimensions of $13 \mathrm{~cm}$ wide by $21 \mathrm{~cm}$ long, which are shown in table 4 .

Table 4. Craft paper sheets made.

\begin{tabular}{|c|c|c|c|}
\hline Sheet & $\%$ BS & $\%$ RP & Photo \\
\hline A & 0 & 100 & \\
\hline B & 20 & 80 & \\
\hline C & 40 & 60 & \\
\hline D & 50 & 50 & \\
\hline E & 60 & 40 & \\
\hline F & 80 & 20 & \\
\hline G & 100 & 0 & \\
\hline
\end{tabular}

As can be seen in the previous table, the sheets obtained show characteristics typical of artisan paper, both on the edges, which are not uniform, and in the distribution of the fibers. In addition, they have a color that ranges from amber yellow to white.

\subsection{Physical properties of the paper produced in this work}

\subsubsection{Determination of grammage or basis weight}

Table 5 shows the average of the replicas made for each of the leaves with different proportions of barley straw and recycled paper, in the same way, the results of sheets of 
bond paper and amate craft paper are obtained. As can be seen, the sample with a lower basis weight was made with $100 \%$ barley straw pulp (G), with $66 \mathrm{~g} / \mathrm{m} 2$, which is closer to the weight of a white sheet of commercial bond paper $(\mathrm{H})$, which should be $75 \mathrm{~g} / \mathrm{m} 2$.

Regarding the other sheets analyzed, these presented a grammage greater than $75 \mathrm{~g} / \mathrm{m} 2$, being the commercial amate artisan paper sheet (I), the one that presented the highest grammage with $143 \mathrm{~g} / \mathrm{m} 2$.

Table 5. Weight and thickness of the sheets analyzed (Standard deviation).

\begin{tabular}{|ccc|}
\hline Sample & $\begin{array}{c}\text { Weight } \\
\left(\mathrm{g} / \mathrm{m}^{2}\right)\end{array}$ & $\begin{array}{c}\text { Thickness or gauge } \\
(\mathrm{mm})\end{array}$ \\
A $(0-100 \% 9$ & $93(3.6)$ & $0.28(1.8)$ \\
B $(20-80 \%)$ & $87(3)$ & $0.25(0.8)$ \\
C (40-60\%) & $82(2)$ & $0.23(2.6)$ \\
D (50-50\%) & $80(1.5)$ & $0.22(0.5)$ \\
E (60-40\%) & $87(3)$ & $0.22(0.5)$ \\
F (80-20\%) & $96(2.5)$ & $0.3(2)$ \\
G (100-0\%) & $66(2)$ & $0.19(0.2)$ \\
Bond Paper Sheet & $75(0.1)$ & $0.09(0)$ \\
Amate Artisan & $143(3.5)$ & $0.34(0.5)$ \\
\hline
\end{tabular}

Prepared samples $C$ and D show a similar basis weight with 80 and $82 \mathrm{~g} / \mathrm{m} 2$ respectively. While manufactured B and E showed a grammage of $87 \mathrm{~g} / \mathrm{m} 2$. According to the Mexican Standard for Bond Paper "NMX-AG-001-IMNC-1999"[34], this type of paper must have a grammage of $75 \mathrm{~g} / \mathrm{m} 2$ which has an interval of 70 to $80 \mathrm{~g} / \mathrm{m} 2$, within which it only classifies sample $\mathrm{D}$, while the other samples show variations.

On the other hand, according to the results obtained, the samples fall into the category of papers, of the classification according to weight [35]: Papers (7-150 g/m2), Cardboards $(140-450 \mathrm{~g} / \mathrm{m} 2)$, Cartons (more than $450 \mathrm{~g} / \mathrm{m} 2)$, which agrees with that reported by Hernández [10], for leaves made by hand from pineapple crown, which presented a grammage of between $63-66 \mathrm{~g} / \mathrm{m} 2$, an interval that also falls within of paper sorting.

According to the weight of the analyzed samples, although it varied from one to another, they all fall within the paper classification since they are below the $150 \mathrm{~g} / \mathrm{m} 2$ mentioned by Márquez [35] and the $180 \mathrm{~g} / \mathrm{m} 2$ established by the UNLP. The variations in the samples are due to the fact that the manufacturing process of the sheets is artisanal and is not standardized, as well as the thickness, this can vary depending on the amount of pulp used when forming the sheet.

On the other hand, the thickness obtained for each sample with its respective standard deviation $(\sigma)$ is observed in the previous table, where the white sheet of commercial bond paper showed the lowest thickness of the analyzed samples with $0.09 \mathrm{~mm}$, followed by the sheet made $100 \%$ with barley straw. 
The mixtures of D and E, showed a thickness of $0.22 \mathrm{~mm}$, while those of $\mathrm{C}$ and $\mathrm{B}$, as well as the $F$ and $G$, presented a thickness of $0.23 \mathrm{~mm}$ and $0.25 \mathrm{~mm}$, respectively. The artisan sheet of commercial amate paper being the one that showed the greatest thickness with $0.34 \mathrm{~mm}$. The thickness of the leaves made with barley straw and recycled paper ranged between 0.19 - 0.0.3 mm, so when comparing these values reported by Hernández [10], with the exception of the one made $100 \%$ with barley straw with $0.19 \mathrm{~mm}$, goes into printing papers, the other sheets fall into the cardboard classification that goes from 0.200 to $1.700 \mathrm{~mm}$.

On the other hand, a thickness of $0.107-0.130 \mathrm{~mm}$ is reported for sheets of artisan paper from pineapple crown, an interval that is below that obtained in the present work. The results obtained are adequate since the paper produced falls within the range of cardboard and printing paper, and this property may vary, by increasing or decreasing the pulp content at the time of sheet formation, so that get to form thinner or thicker papers such as cardboard.

3.4.2. Paper Resistance to Bursting (Mullen)

The results obtained for this test are presented in table 6.

Table 6. Pressure obtained for each of the samples in KPa (Standard deviation $\sigma$ ).

\begin{tabular}{|cc|}
\hline Sample & $\begin{array}{c}\text { RESISTANCE TO BURST } \\
\text { PRESSURE (KPa) }\end{array}$ \\
A (0-100\%) & $75.8(1)$ \\
B (20-80\%) & $103.4(1)$ \\
C (40-60\%) & $68.9(0.5)$ \\
D (50-50\%) & $96.5(1)$ \\
E (60-40\%) & $79.9(1.1)$ \\
F (80-20\%) & $96.5(2)$ \\
G (100-0\%) & $89.6(1)$ \\
Sheet of Bond Paper & $117.2(1)$ \\
Amate Craft Papel & $144.8(1)$ \\
\hline
\end{tabular}

Figure 3 shows the results obtained in $\mathrm{KPa}$, it can be seen that the samples with the lowest values are those made with BS-RP, with an interval of 68-104 Kpa. 


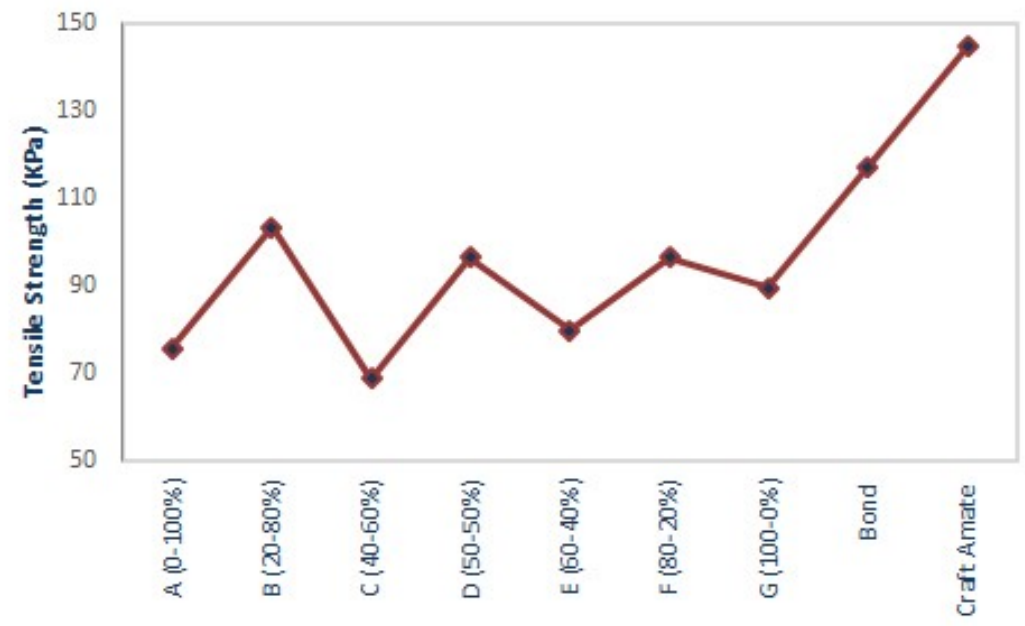

Figure 3. Burst resistance in craft paper sheets.

As for the commercial sheets of both bond paper and artisan sheet, they present a greater resistance to bursting with 117 - $145 \mathrm{KPa}$. Close to the Aguilar [36] report, for paper made with banana fiber with a range of $96-170 \mathrm{KPa}$, a value that includes the resistance obtained for the commercial sheets analyzed in this study, bond paper and artisan sheet. Regarding the leaves made with barley straw and recycled paper, the values obtained fall within the range mentioned by Aguilar [36], for paper made with Cuban fiber, which is 27-91 KPa. According to the Mexican Standard NMX-N-087-SCFI-2008 [14], the analyzed samples have a burst resistance similar to that shown by newsprint, and the samples that are closest to the value reported for printing paper are the two commercial sheets of both bond paper and craft. Therefore, the values obtained in the burst resistance test are low, which is why they enter into newspaper and it is necessary to improve the production of sheets to obtain greater resistance.

\subsection{SEM Analysis}

On the other hand, figure 4 shows the photomicrographs of the papers produced, where it can be seen that the different morphologies of the fibers present a certain homogeneity between them and a cylindrical morphology with an average width ranging between $15 \mu \mathrm{m}$ and $20 \mu \mathrm{m}$. Likewise, a low porosity can be observed, which makes this material present properties similar to commercial craft paper, which could be further improved by implementing a different treatment. 


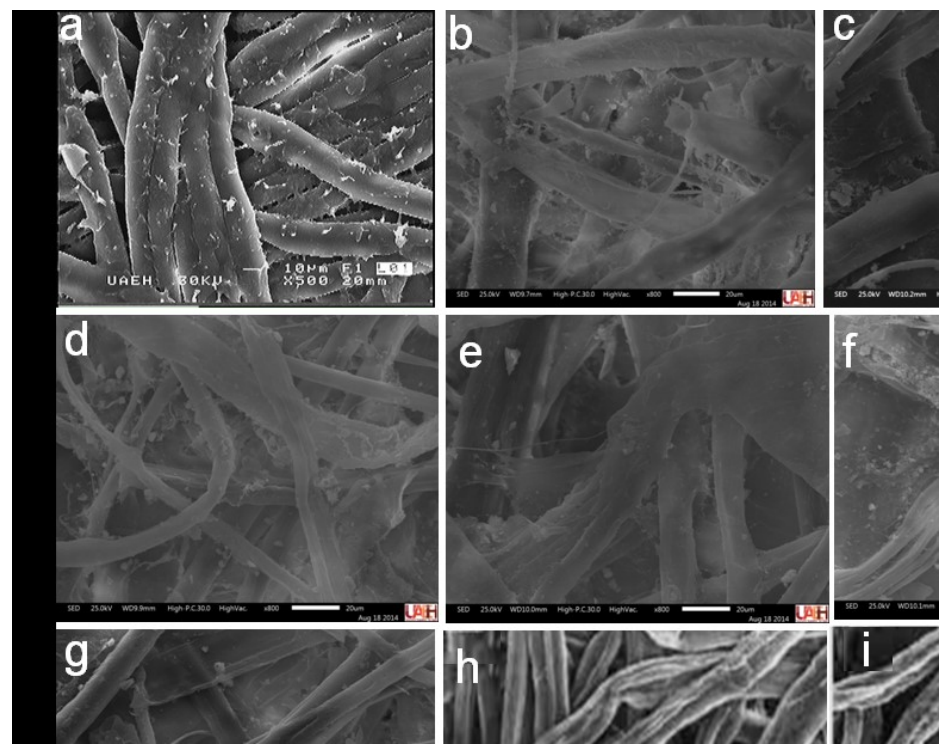

Figure 4. Photomicrographs of the material produced a) Sheet of commercial craft paper, b) sheet of recycled paper 0\% BS -100\% RP, c) 40 BS -60\% RP, d) 50 BS -50\% RP, e) 60 BS -40\% RP, f) 80 BS -20\% RP, g) ( 100 BS - 0\% RP, h) Bond Paper Sheet, Amate Craft Paper.

\subsection{Infrared analysis}

Figure 5 shows the chemical characterization based on the links of the functional groups present in the barley straw sample and the leaf obtained from the treated barley straw between the wavelength ranges of $424-511 \mathrm{~cm}-1$, there are the bands of phosphate groups, in $594 \mathrm{~cm}-1$ with a stretching band of $\mathrm{CH}$ bond, of 700-650 cm-1 and torsion bands of $\equiv \mathrm{CH}$, of 960-875 cm-1 bands of torsion of carboxylic acids with $\mathrm{C}=\mathrm{O}$ bonds, in $1033 \mathrm{~cm}-1$ torsion band outside the amine plane with $\mathrm{NH}$ bond, at $1114 \mathrm{~cm}-1$ there is an amine torsion band but now it is not out of plane, in $1152 \mathrm{~cm}-1$ there is an ether stretch band with $\mathrm{CO}$ bond, at $1242 \mathrm{~cm}-1$ alcohol stretch band with $\mathrm{C}-\mathrm{OH}$ bond, at $2667 \mathrm{~cm}-1$ there is a stretch band with CH3-C bond, at $1375 \mathrm{~cm}-1$ there is a methyl torsion band with $\mathrm{CH}$ bond, at $1454 \mathrm{~cm}-1$ torsion band of a methylene with $\mathrm{CH}$ bond, at 1482 there is a $\mathrm{fl}$ band connection with $\mathrm{CO}$ bond, for 1629 there is a terminal vinyl with $=\mathrm{CH}$ bond, an aldehyde with stretch band is found at $1737 \mathrm{~cm}-1$ with $\mathrm{C}=\mathrm{O}$ bond, at $1843 \mathrm{~cm}-1$ there is a double carbonyl band with symmetric stretching, at $2052 \mathrm{~cm}-1$ terminal acetylene with $\mathrm{C} \equiv \mathrm{C}$ bonds and $\mathrm{A} 2464 \mathrm{~cm}-1$ a central acetylene with $\mathrm{C} \equiv \mathrm{C}$ bonds, between 2464-2551 there are double bond tension bands of $\mathrm{C}=\mathrm{C}$, at $2853 \mathrm{~cm}-1$ there are a symmetric stretch band with $\mathrm{CH}$ bond, at $2853 \mathrm{~cm}-1$ there is an asymmetric stretch band of methylene with $\mathrm{CH}$ bond and between 3435-370 cm-1 are the bending bands from a hydroxyl group to a polymer, as well we know cellulose is a polymer.

The bands that showed the greatest change, both in band width and intensity are those of the hydroxyl groups; In the untreated barley bands the width of the beak is smaller compared to that of the paper made with the treated barley straw, the increase in the intensity of the base (width of the beak) is based on the elongation of the hydrogen bonds and the 
bending of the $\mathrm{OH}$ that are attached to the cellulose structure, increasing the absorption of water [37].

The $1737 \mathrm{~cm}-1$ band corresponds to the stretching vibration of the $\mathrm{C}=\mathrm{O}$ groups of the residue of acetyl groups and esters of pectin, hemicellulose or of the uronic ester bonds of the carboxyl groups in the ferulic and p-coumaric acids of lignin and hemicellulose [38]. As can be seen in the image, the band that may correspond to those compounds appears in both, but they do not present any greater intensity and the peak maintains the same width.

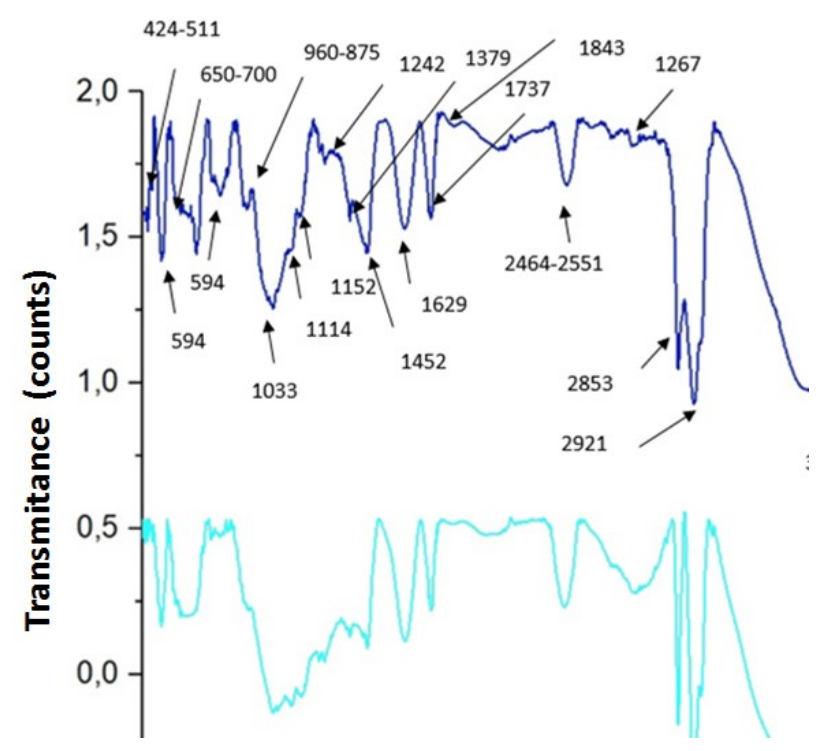

Figure 5. Infrared spectra of the target (barley straw) and paper made from barley straw with treatment.

In Figure 6, the results of the sheet of paper made with 100\% recycled paper, the sheet with $50 \%$ barley straw and 50\% recycled paper are shown, and again the sheet of paper with $100 \%$ recycled paper is presented. treated barley straw. Making the comparison in the spectrum corresponding to the recycled paper sheet, the bands of $424-511 \mathrm{~cm}^{-1}$ that correspond to phosphate groups are not shown, but if they are present in the two remaining spectra, this is due to the fact that the mineral substances of Grain cereals (without shell) and dressed grain (with shell) are mainly composed of phosphates, sulfates of potassium, magnesium and calcium [39]. Another of the most notable differences is that the $1737 \mathrm{~cm}^{-1}$ band corresponding to the carbonyl groups is not present in the recycled paper sheet and this is due to the fact that it does not contain lignin, hemicellulose and pectin. 


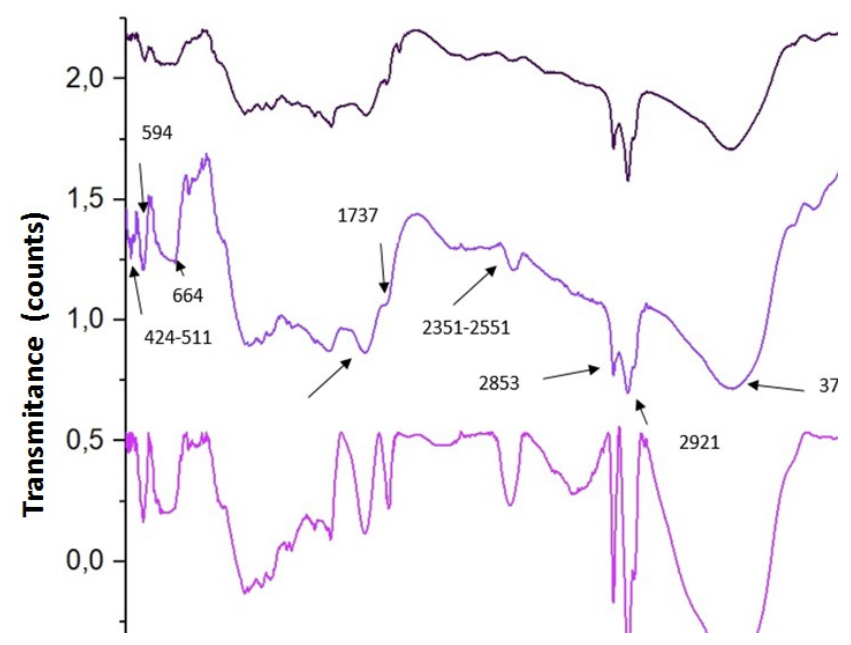

Figure 6. Infrared spectrum of the recycled paper sheet, 50\% barley straw and 50\% recycled paper sheet, and the treated barley straw sheet.

\subsection{X-ray diffraction}

By means of X-ray diffraction analysis, the spectra of figure 7 were obtained, and table 7 shows the data of the comparison of the phases, crystal size, interplanar distance and family of planes corresponding to lignin and cellulose.

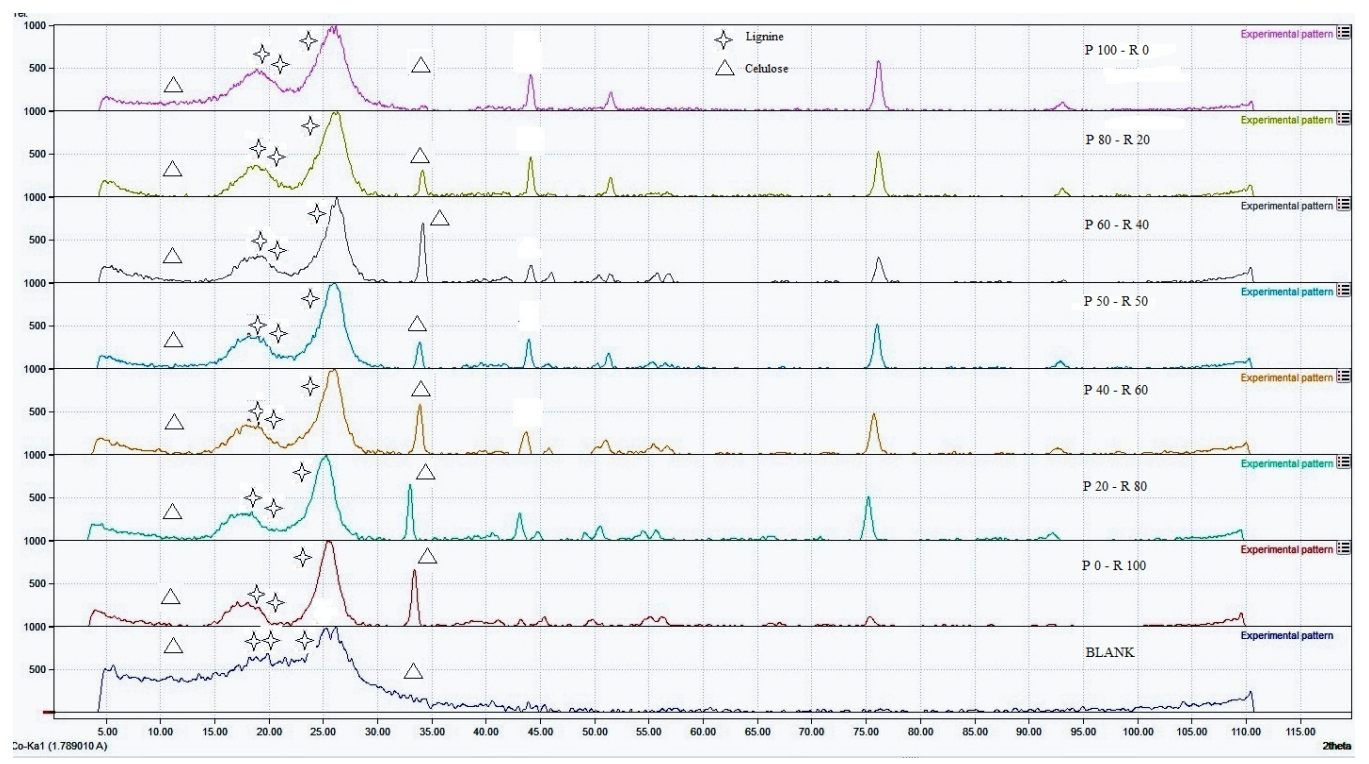

Figure 7. Diffractograms of the treatments for the elaboration of paper where barley straw $(\mathrm{P})$, recycled paper (R), and native straw (White Ps / t) with lignin phases with angles $\sigma, 18.5^{\circ}, 19.9^{\circ}$ and $25^{\circ}$; cellulose with angles $\sigma, 12^{\circ}, 35^{\circ}$ and $46^{\circ}$. 
From the diffractograms obtained that correspond to barley straw without any treatment. The sheet made with $100 \%$ recycled paper, 50\% barley straw sheet and $50 \%$ recycled paper, and the sheet made with $100 \%$ barley straw was considered as shown in spectrum 2 .

The diffractograms were analyzed to determine the peaks corresponding to lignin and cellulose. Which were indexed using the Match program, obtaining peaks of $18.5^{\circ}, 19.9^{\circ}$ and $25.0^{\circ}$ for lignin, these are in the ranges reported by Viveros [40] that indicates the peaks for lignin are between $16^{\circ}$ and $22.5^{\circ}$.

For cellulose, the angles found in the paper sheets made with barley straw with a previous treatment for its use and recycled paper varied according to the percentages implemented for its elaboration. The peaks corresponding to cellulose of each leaf, in general were found between $12^{\circ}, 18^{\circ}, 35^{\circ}$ and $46^{\circ}$, some of these peaks were found among those reported by Garcia [41] indicating that there are peaks for cellulose at $12.6^{\circ}, 20.6^{\circ}, 22.3^{\circ}$ and $35.3^{\circ}$.

From shots of a superficial portion of the paper sample prepared to be analyzed in X-ray diffraction; The peaks were measured together with the values of each $K_{\alpha 1}$ radiation that were obtained in the curved detector diffractometer. Later they were calculated and analytically solved for the angular values of $\theta$ up to 110 degrees; in addition, the $2 \theta$ values for $\alpha$ were listed; The interplanar distance, lattice parameter, Miller indices, crystallite size, and crystallinity of each phase were calculated, and the process was followed to complete the X-ray diffraction pattern.

In Figure 7, you can see the diffractogram of the sample containing the substrate of the artisan paper studied. For barley straw (lignin), 5 peaks were identified, and the barley straw whose PDF is [96-151-9021 ], and the crystal structure was determined using the analytical method for a tetragonal structure [42]. Determining that it presents a crystalline structure with $d=2.11$, a cell parameter a $=2.109 \AA$, with a crystallite size of $37 \AA$, and the Miller indices were calculated to know its crystalline structure, finding the following: lignin [2 7 5] tetragonal, with a percentage of crystallinity of $22.8 \%$.

For P100-R0 (cellulose) barley straw paper 100\% - Recycled 0\%, 7 peaks were identified, and the barley straw whose PDF is [96-721-5922] were indexed, and the crystalline structure [42]. Determining that it shows a monoclinic crystal structure with $d=2.7 \AA$, and

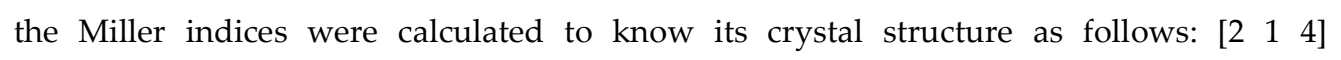
monoclinic. $37.1 \%$ crystallinity percentage. and crystallite size $15 \AA$.

For P50-R50 (50\% barley straw paper- 50\% recycled), 8 peaks were identified, and the barley straw whose PDF is [96-201-9437] were indexed, and the crystalline structure was determined using the analytical method. Determining that it presents a monoclinic crystalline structure with $d=1.5 \AA$, Miller indices were calculated to know its crystalline structure as follows: $\left[\begin{array}{lll}4 & 1 & 4\end{array}\right]$ monoclinic. Percentage crystallinity of $31.5 \%$, and crystallite size $7.3 \AA$.

For P0-R100 (cellulose) $0 \%$ barley straw-100\% recycled paper, 7 peaks were identified, and the barley straw whose PDF is [96-721-0492] were indexed, and the crystalline structure was determined orthorhombic with $\mathrm{d}=2.1 \AA$, Miller indices were calculated to determine its crystal structure as follows: $\left[\begin{array}{lll}0 & 2 & 2\end{array}\right]$ orthorhombic. $34.4 \%$ crystallinity percentage. and crystallite size $21 \AA$. 
From the analysis of the diffractograms, it appears that the change of each of the sheets of paper made with the different treatments with respect to the barley straw without any treatment present Gaussian-type peaks, which indicates that the crystal size is smaller although the crystals are more abundant, for each of the peaks and with different treatments.

The crystal size possibly increases with the presence of lignin, and its heat treatment. Said crystals presented a modification after the rupture of the lignin molecules, and the transformation of the cellulose by means of the alkaline heat treatment carried out to obtain the pulp.

The change presented by the leaves is observed with the displacement of the peaks to the right with a lower angle $\sigma$ and a small increase in the cell, with greater definition of the peaks and the appearance of new ones; this indicates an improvement in the percentage of crystallinity and a decrease in the crystallite size.

By contrasting what is observed in the diffractograms of the image with respect to resistance to bursting, we find that the leaves with barley straw improve their resistance to bursting, which is shown in figure 7 , and the percentages of crystallinity of cellulose for the leaves considering only the straw without any treatment, the P100-R0, P50-R50, P0-R100 leaf.

It was considered to have as upper limit the sheet made with $100 \%$ recycled paper, an intermediate of both combinations, and as the lower limit the sheet made with $100 \%$ barley straw and a blank to observe the change after carrying out the thermal-alkaline treatment.

As mentioned before, comparing with resistance to bursting, the results obtained indicate that the crystallinity is better in the leaves with the highest amount of barley straw, the leaf with the highest percentage of crystallinity is the one made with $100 \%$ barley straw with a percentage of crystallinity of $37.1 \%$, followed by the sheet made with $100 \%$ recycled paper with a value of $34.4 \%$ and finally the combination P50-R50 with a percentage of $31.5 \%$, and we know that the treatment worked to increase the crystallinity at a rate that the blank presented a percentage of crystallinity of $22.8 \%$.

Although this was not enough compared to what was reported by García [41] in table 7, for paper made from sugar cane straw after obtaining cellulose by a pulping method and a homemade method.

The values obtained from the barley straw leaves and recycled paper are half of those obtained by the homemade method for sugar cane straw paper.

Table 7. Characteristics of pulp extracted with the pulping method and home method.

$\begin{array}{lll}\text { Characteristics } & \text { Pulping method cellulose } & \text { Home method cellulose } \\ \text { FWHM } & 3.726 & 3.82 \\ \text { 2-Theta }\left(^{\circ}\right) & 20.6 & 20.66 \\ \text { Crystalline area } & 629 & 637 \\ \text { \% of crystallinity } & 74.78 \% & 64.24 \% \\ \text { Crystal size } & 22 A^{2} & 22 \mathrm{~A}^{2}\end{array}$




\section{Conclusions}

After the results obtained, it is observed that the treatment carried out allows the release of cellulose through delignification.

What is observed in the SEM images allows us to infer that the straw has the function of supporting the leaves with combinations of barley straw and recycled paper. The result of the IR analysis indicates that the leaf with an increase in hydroxyl groups was that of barley straw, therefore, the treatment was efficient and among the other leaves analyzed it is the one with the highest crystallinity, this result was corroborated by X-ray diffraction analysis, in which the percentage of crystallinity of the barley straw paper was $37.1 \%$ exceeding the percentage that the initial barley straw had, which was $22.8 \%$, and in the same way with the mixture and with the recycled paper of the treatments for the elaboration of the paper where barley straw $(\mathrm{P})$, recycled paper $(\mathrm{R})$, and native straw (White Ps / t ) with lignin phases of orthorhombic structure with angles $\sigma, 18.5^{\circ}, 19.9^{\circ}$ and $25^{\circ}$; cellulose monoclinic structure with angles $\sigma, 12^{\circ}, 35^{\circ}$ and $46^{\circ}$.

The results obtained indicate that the crystallinity is better in the leaves with the greatest amount of barley straw, the leaf with the highest percentage of crystallinity is the one made with $100 \%$ barley straw with a percentage of crystallinity of $37.1 \%$, followed by the elaborated leaf with $100 \%$ recycled paper with a value of $34.4 \%$. Despite the fact that the results obtained were good, the crystallinity percentages are half of those reported for other types of lignocellulosic materials. For this reason, it would be convenient to carry out a different treatment on the same samples and rely on the barley straw leaf to analyze whether the characteristics improve or worsen. With this evaluation, it could be determined if it is feasible to implement only barley straw or a mixture considering the costs and yields of each of them.

Author Contributions: Conceptualization, J. H-A, A.D. R-G and A. K. V-M.; methodology, A.D. R-G, E. C-S and E. S-R; software, A. K. V-M.; validation, E. C-S and A.D. R-G; formal analysis, A.D. R-G, E. S-R and J. H-A investigation, A. K. V-M.; data curation, J. H-A; writing —original draft preparation, J. H-A and E. S-R; writing - review and editing, A.D. R-G and E. C-S; visualization, A.D. R-G; supervision, E. S-R and J. H-A; project administration, J. H-A, E. S-R, A.D. R-G. All authors have read and agreed to the published version of the manuscript.

Funding: This research received no external funding.

Data Availability Statement: In this section, please provide details regarding where data supporting reported results can be found, including links to publicly archived datasets analyzed or generated during the study. Please refer to suggested Data Availability Statements in section "MDPI Research Data Policies" at https://www.mdpi.com/ethics. You might choose to exclude this statement if the study did not report any data.

Acknowledgments: The authors want to thank the CONACyT of the Mexican Government for the support for the SNI distinction as research members and the encouragement received each month.1. Authors also thank Authors also thank To the academic support program PRODEP of the Secretary of Public Education of México, and To the company "BIOPAPPEL KRAFT", for allowing me to carry out the corresponding analyzes at their facilities.

Conflicts of Interest: The authors declare no conflict of interest. 


\section{References}

1. Lugo, I. M. (2017). Reporte de la Industria del Papel. http://mnamexico.com/wp-content/uploads/2017/05/Industria-Papel-4.pdf

2. Vargas Morales Antonia Karina, (2013), Obtención de Papel Artesanal Empleando Diferentes Proporciones de Paja de Cebada. Tesis profesional. Universidad Autonoma del Estado de Hidalgo.

3. Aguilar, B. B. (2012). Estructuración de la hoja de papel . Guadalajara, Jalisco : Encuadernaciones

4. García, T. E. (2006). Metodología para la fabricación de papel echo a mano, amate y papiro. Jalisco: Emiliano Zapata.

5. García-García, G., Stone, J. y Rahimifard, S. (2019). Oportunidades para la valorización de residuos en la industria alimentaria: un estudio de caso con cuatro fabricantes de alimentos del Reino Unido. Journal of Cleaner Production , 211 , 1339-1356. https://doi.org/10.1016/j.jclepro.2018.11.269

6. Castillo Ramírez, Claudia Denisse. (2005). Uso alternativo de las cebadas (hordeum sativum jess) cultivadas en los Estados de Hidalgo y Tlaxcala en la industria de la panificación. Tesis de licenciatura. UAEH.

7. AOAC. 1990. Official Methods of Analysis of the Association of Official Analytical Chemists. $15^{\text {Th }}$ edition. Vol. II. Edited by Kenneth Helrich. Pp 777-781, 1095-1096.

8. Cruz Lugo, A. L. (2007). Correlación del método Kjeldahl con el método de combustión Dumas automatizado para determinación de proteína en alimentos.

9. Wise, (1946) en; San Juan-Dueñas, R., Guía práctica para la especialidad en celulosa y papel I. Universidad de Guadalajara.

10. Hernández Ortega, M. (2008), Elaboración y caracterización del papel artesanal de la corona del fruto de dos variedades de piña Ananas comosus (L.) Merr/por Maricela Hernández Ortega (No. TESIS.).

11. Al Arni, S., Zilli, M., \& Converti, A. (2007). Solubilization of lignin components of food concern from sugarcane bagasse by alkaline hydrolysis disolución de componentes lignínicos de interés alimentario a partir de bagazo de caña de azúcar por hidrólisis alcalina. Cyta-Journal Of Food, 5(4), 271-277. https://doi.org/10.1080/11358120709487701

12. NMX-N-001-SCFI-2005.Industrias De Celulosa Y Papel - Determinación Del Gramaje O Peso Base Del Papel, Cartoncillo Y Cartón (Peso Por Unidad De Área) - Método De Prueba.

13. NMX-N-009-SCFI-2005. Industrias de Celulosa y Papel-Espesor y Peso EspecIfico de Papeles y Cartoncillos-MEtodo de prueba.

14. NMX-N-087-SCFI-2008. Industrias De Celulosa Y Papel-Resistencia Del Papel Al Estallido (Mullen)- Método De Prueba.

15. Cuervo, L., Folch, J.L., Quiróz, R.E. 2009. Lignocelulosa como fuente de azúcares para la producción de etanol. Biotecnología. 13(3):11-25

16. Barba Pacheco, Claudia, (2002). Síntesis de Carboximetilcelulosa (CMC) a partir de pastas de plantas anuales. Tesis Doctoral. Universitat Rovira I Virgili. Tarragona. https://www.tdx.cat/handle/10803/8503\#page=1 (accessed on 13 December 2018).

17. Pepijn, Prinsen, (2010). Composición química de diversos materiales lignocelulósicos de interés industrial y análisis estructural de sus ligninas. Tesis Doctoral. Universidad de Sevilla. https://digital.csic.es/handle/10261/66265 (accessed on 2 february 2019).

18. Téllez García, Román Alejandro, (2008). Obtención de pulpa celulósica a partir de la madera Mangifera indica L. Mango. Por el proceso organsolv modificado. Tesis profesional. Universidad Michoacana de San Nicolás de Hidalgo.

19. Torres, M., Juacida, R., \& Rodríguez, S. (2002). Composición química, obtención de pulpa Kraft y su evaluación papelera en castaño, ciprés y encino. Bosque, 23(1), 125-130.

http://revistas.uach.cl/index.php/bosque/article/view/5510

20. Contreras-López, E., Jaimez-Ordaz, J., Hernández-Madrigal, T., Añorve-Morga, J., \& Beltrán-Hernández, R. (2008). Composición química de cebadas cultivadas bajo diferentes condiciones de labranza en tres localidades del estado de 
Hidalgo, México. Bioagro, 20(3), 201-208. https://www.redalyc.org/pdf/857/85714153007.pdf (accessed on 3 December $\underline{2018)}$.

21. Seoánez Calvo, M. (2000). Manual de contaminación marina y restauración del litoral: contaminación, accidentes y catástrofes, agresiones a las costas y soluciones: el turismo de costa, la pesca, la ordenación y la gestión del litoral (No. 04; GC1085, S4.).

22. Yescas, R. Y., Gama, R. B., Martínez, G. D. M., Muñoz, S. S. G., Peralta, M. C., \& Cerrilla, M. E. O. (2004). Digestibilidad in situ de dietas con rastrojo de maíz o paja de avena con enzimas fibrolíticas. Agrociencia, 38(1), 23-31. https://www.redalyc.org/pdf/302/30238103.pdf

23. Jiménez, L., Rodríguez, A., \& Ferrer, J. L. (2006). Caracterización química de materias primas alternativas para pastas celulósicas. INGENIERIA QUIMICA-MADRID-, 38(441), 86.

24. Pejó, M. E. T. (2009). Bioetanol de paja de trigo: estrategias de integración de las etapas de proceso (Doctoral dissertation, Universidad Complutense de Madrid).

25. Torres, G., Arbaiza, T., Carcelén, F., \& Lucas, O. (2009). Comparación de las técnicas in situ, in vitro y enzimática (celulasa) para estimar la digestibilidad de forrajes en ovinos. Revista de Investigaciones Veterinarias del Perú, 20(1), 5-9. http://www.scielo.org.pe/pdf/rivep/v20n1/a02v20n1.pdf

26. González-Rentería, S. M., Soto-Cruz, N. O., Rutiaga-Quiñones, O. M., Medrano-Roldán, H., Rutiaga-Quiñones, J. G., \& López-Miranda, J. (2011). Optimización del proceso de hidrólisis enzimática de una mezcla de pajas de frijol cuatro variedades (Pinto villa, Pinto saltillo, Pinto mestizo y Flor de mayo). Revista mexicana de ingeniería química, 10(1), 17-28. http://www.scielo.org.mx/scielo.php?script=sci arttext\&pid=S1665-27382011000100003

27. Bartaburu, Danilo. Montes, Esteban. Pereira, Marcelo, (2006). Utilización de la paja de arroz en la alimentación animal. Revista (INIA) Instituto Nacional de Investigación Agropecuaria.

28. Orihuela Equihua Rocío, (2011). Posibilidades de uso de higuerilla (Ricinuscommunis L.) en la obtención de celulosa a la sosa, blanqueada [OD (OP)D] para su uso en papel bond. Tesis profesional. Universidad Michoacana de San Nicolás de Hidalgo.

29. Jiménez, L., (2002). Obtención de pastas celulósicas de residuos agrícolas mediante procesos con disolventes orgánicos. Congreso iberoamericano de investigación de celulosa y papel (CIADICYP).

30. Juacida P. Roberto., Rodríguez S. Sandra., Torres U. Marco., 2002. Composición química, obtención de pulpa Kraft y su evaluación papelera en castaño, ciprés y encino. Notas técnicas.Instituto de Tecnología de Productos Forestales, Universidad Austral de Chile, Valdivia.

31. Marques Silva, Gisela (2010). Valorización de diferentes cultivos lignocelulosicos para la fabricación de pasta de papel: Caracterización química, modificación estructural de sus constituyentes orgánicos durante los procesos de cocción y BL (Doctoral dissertation, Tesis de doctorado, Universidad de Sevilla, España).

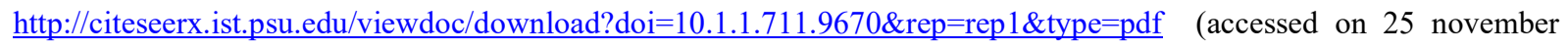
2018)

32. Quintero, R. (2009). Biocombustibles lignocelulósicos: Estado del arte. Segundo Seminario de Divulgación. Ventajas y Desventajas de las Energías Alternativas: El Caso de los Biocombustibles.

33. Giménez A.M., Calatuya F., Figueroa M.E., Diáz Zirpolo J., (2012). Anatomía de leño de Maytenus vitis-idaea y M. viscifolia (Celastraceae). Bol. Soc. Argent. Bot. Argentina.

34. NMX-AG-001-IMNC-1999, Papel Bond Offset Blanco 75 G/M² En Extendido Para Impresion Offset De Libros Y Revistas-Especificaciones. 
35. Márquez Elio. R., 2001. Papeles y cartones. Instituto de diseño de Valencia. Guia de empaque I.

36. Aguilar, S., Ramírez, J., \& Malagón, O. (2007). Extracción de fibras no leñosas: Cabuya (Furcraea andina Trel.) y Banano (Musa paradisiaca L.) para estandarizar un proceso tecnológico destinado a la elaboración de pulpa y papel. Revista Iberoamericana de polímeros, 8(2), 89-98.

37. Lojewska, J., Miśkowiec, P., Lojewski, T., \& Proniewicz, L. M. (2005). Cellulose oxidative and hydrolytic degradation: In situ FTIR approach. Polymer degradation and stability, 88(3), 512-520.

38. Naranjo, C. D.-B.-L.-R.-F. (2014). Aislamiento y caracterización de celulosa obtenida de firbras de Agave Salmiana aplicando dos metodos de extracción ácido-alcali. Mexicana de Ciencias Agricolas, 31-43

39. Madrigal, H., \& Samanta, T. (2006). Estudio de la composición química de cebada cultivada en Zapotlan, Villa de Tezontepec y Tultengo, Hidalgo. http://dgsa.uaeh.edu.mx:8080/bibliotecadigital/handle/231104/1741 (accessed on 18 December 2018).

40. Vivero, M. R. (2016). Determinación de la cristalinidad y de la accesibilidad de las fibras de celulosa mediante diferentes técnicas.

https://www.tdx.cat/bitstream/handle/10803/6489/16Brv16de20.pdf?sequence=16

41. García, E. Y., GS, S., Bolio, L. G. I., Córdova, S. S., Lagunes, E. L. C., \& Falconi, C. R. (2015). Elaboración de papel artesanal con paja de caña de azúcar. La innovación tecnológica para la seguridad alimentaria.

42. Suryanarayana, C., \& Norton, M. G. (1998). X-rays and Diffraction. In X-Ray Diffraction (pp. 3-19). Springer, Boston, MA. 